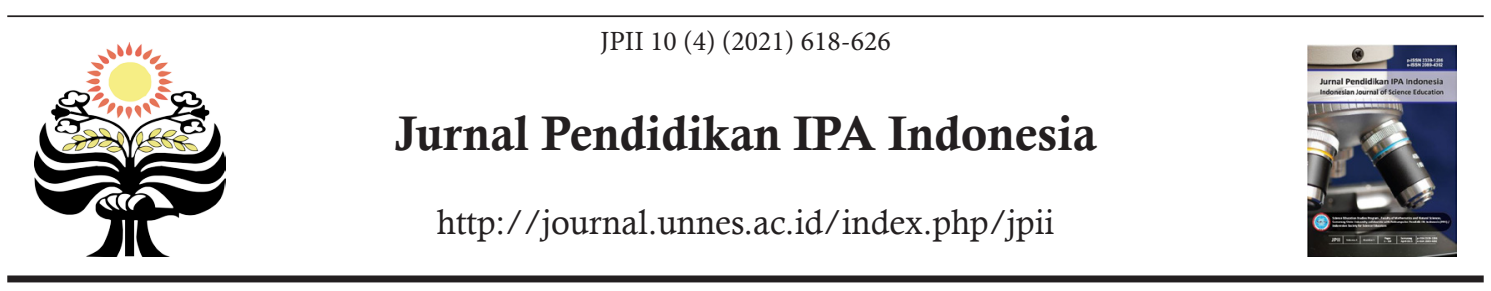

\title{
MURDER LEARNING MODEL ASSISTED BY METACOGNITIVE SCAFFOLDING TO IMPROVE STUDENTS' SCIENTIFIC LITERACY AND NUMERACY SKILLS THROUGH SCIENCE STUDIES IN ELEMENTARY SCHOOLS
}

\author{
I. M. Tegeh*1 , I. G. Astawan' ${ }^{2}$ I. K. Sudiana ${ }^{3}$, M. G. R. Kristiantari ${ }^{4}$ \\ 1,2,3,4Universitas Pendidikan Ganesha, Indonesia
}

DOI: 10.15294/jpii.v10i4.32926

Accepted: October $19^{\text {th }} 2021$. Approved: December $27^{\text {th }} 2021$. Published: December $31^{\text {st }} 2021$

\begin{abstract}
Teachers have not systematically handled science learning. Due to teachers' lack of creativity in creating science learning that provides learning experiences, students cannot develop literacy and numeracy. Preliminary research studies found low learning outcomes in science studies with significant literacy and numeracy skills weaknesses. This study aims to analyze the effect of the Murder learning model assisted by Metacognitive Scaffolding on students' scientific literacy and numeracy skills through science studies in elementary schools. With a non-equivalent posttest-only control group design, this research is a quasi-experimental study. The population in this study was 173 people, while 60 people divided into two classes were chosen by random sampling. Data on scientific literacy and numeracy skills were collected using a test instrument which consisted of 35 questions. The instrument was gone through a validation process to measure its validity and reliability. A MANOVA test with the IBM SPSS Statistics 21.0 program was utilized to analyze the data. The hypothesis test obtained a significance value of 0.000 (Sig <0.05). The average score of scientific literacy skills was 77.67 , and 75.37 for numeracy skills. Based on this, it can be concluded that there is a significant effect of the Murder learning model assisted by Metacognitive Scaffolding on students' scientific literacy and numeracy skills through science studies in elementary schools.
\end{abstract}

(C) 2021 Science Education Study Program FMIPA UNNES Semarang

Keywords: murder; scaffolding; scientific literacy; numeracy

\section{INTRODUCTION}

One of the subjects that provide opportunities for students to construct their knowledge according to the rules of scientific attitudes, scientific processes, and scientific products is science (Redhana, 2013; Kurniawati et al., 2017; Subali et al., 2019). Science learning material is closely related to itself and the environment in everyday life (Maison et al., 2020; Lo et al., 2021). Science learning becomes essential to students, especially at the elementary school level. At the elementary school level, science learning aims to form students who think critically, logically, heed scien-

*Correspondence Address

E-mail: im-tegeh@undiksha.ac.id tific principles, and care about the environment. The aim is in line with the demands of 21 stcentury learning, which emphasizes the ability of students to collect information from various sources, formulate and solve problems, think analytically, critically, and creatively, and collaborate in solving problems.

Teachers must realize that the environment or the natural surroundings can be studied easily, with the aim that students' scientific attitudes continue to develop. However, the situation on the ground was not as expected. Teachers have not systematically handled science learning. Teachers are pretty uncreative in creating fun science learning (Parmin et al., 2015; Paramitha et al., 
2016). In addition, teachers do not develop innovative learning processes (Wijanarko, 2017; Elisabet et al., 2019). The quality of students from learning outcomes has a gap with the program launched or the efforts made to improve the quality of education. One of the causes of this gap is the application of the learning model in the teaching and learning process (Ratih, 2017; Suari, 2018). The conventional learning model applied by the teacher causes the formation of passive behavior or only accepting without protest (Bahari et al., 2018; Suantara et al., 2019).

Based on the initial observations, conventional learning is still a transformation of knowledge through lectures, questions and answers, assignments, and descriptions, where the leading role is the teacher. It means that teachers are the main actors in learning that make the activities successful (Arisantiani et al., 2017; Wardani \& Syofyan, 2018). The teacher is very active in planning, implementing, and evaluating, while students passively listen to the teacher's explanation and observe what the teacher is doing. Students only memorize and stem theoretical knowledge, without any practice that implies students have experience. The opportunity for students to relate learning materials to things they feel in everyday life is minimal or even invisible, which impacts the low learning outcomes of science.

There are many ways creative and professional teachers can improve student learning outcomes (Ayuni et al., 2017; Widani et al., 2019; Andriyani \& Suniasih, 2021). One of the changes in the learning paradigm is that the orientation of learning which was originally teacher-centered has shifted to student-centered. In addition, the model, which was initially more dominated by expository, has changed to participatory, and the approach, which was initially more textual, has turned into contextual. The learning model that puts students through many interactions with other students is the cooperative learning model (Novianti, 2017; Nurhusain, 2017; Haryono, 2020). Cooperative learning is known as group learning. The Murder-type cooperative learning model emphasizes the students' ability to reconstruct information and ideas received, understand them, which are then communicated orally or in writing (Liebech-Lien, 2021; Tan et al., 2021). Murder-type cooperative learning activities are divided into six main activities: (1) mood, (2) understanding, (3) recall, (4) detect, (5) elaborate, and (6) review (Ayunani, 2013; Darmika et al., 2014),

The use of the Murder model provides a concrete way for students to develop mastery of concepts and opportunities for students to work cooperatively with their friends (Rahmadhani et al., 2019; Serli et al., 2020). This learning model also provides broad opportunities for students to express concepts or ideas that they already have, test, and discuss these ideas openly. In Murder cooperative learning steps, the teacher presents information and phenomena related to learning activities to stimulate students' curiosity. In this case, information processing skills take precedence. Information processing demands the involvement of metacognitive (metacognitive knowledge and skills) thinking and making decisions based on thinking (Koopman et al., 2011; Chuprina et al., 2016; Purnami et al., 2021).

Metacognitive learning focuses on student learning activities, assisting and guiding students with difficulties, and helping students develop selfconcepts of what to do while studying (Binali et al., 2021; De Backer et al., 2022). Following this, the relevant learning model to overcoming these problems is the Murder learning model assisted by Metacognitive Scaffolding. The Murder model assisted by Metacognitive Scaffolding combines the Murder model with metacognitive assistance (metacognitive scaffolding). Murder model with Metacognitive Scaffolding is a cooperative learning model that compares and regulates student learning which includes planning, monitoring, and evaluation of students' knowledge by providing support in the form of temporary assistance (scaffolding) (Molenaar et al., 2010; Zheng et al., 2019; Serli et al., 2020).

The Murder model assisted by Metacognitive Scaffolding sets students up to study in small groups of 4 students (Royanto, 2012). Each group is divided into two small groups that replace the function of the dyad members, the small group dyad1 and dyad2. Each small group has a different task. One small group functions to manage, process, and verbally present information, while the other small group functions to record, manage, and process information in notes or a product such as a summary or a resume. One with other small groups can exchange roles for having the same abilities and skills later. The Murder model assisted by Metacognitive Scaffolding combines Murder type cooperative learning with six learning steps with metacognitive scaffolding in metacognitive questions, quick questions, and feedback (Royanto, 2012; Wesiak et al., 2014). The Murder model assisted by Metacognitive Scaffolding adheres to constructivism learning theory. The constructivist theory view that learning success depends not only on the learning environment or conditions but also on students' prior 
knowledge (Duane \& Satre, 2014; Pande \& Bharathi, 2020; Suwannaphisit et al., 2021). Thus, students who find the initial concepts of knowledge learn without always depending on the teacher to solve problems. This situation impacts more active, motivated, and creative students in solving problems.

The previous research findings stated that the cooperative learning model makes the learning atmosphere fun (Khan \& Masood, 2015; Nurhusain, 2017; Demitra \& Sarjoko, 2018). The Murder learning model can make it easier for students to learn (Darmika et al., 2014; Rahmadhani et al., 2019). There is no study on the Murder Model assisted by Metacognitive Scaffolding, which combines the cooperative learning model with metacognitive scaffolding. This study aims to determine the effect of the Murder learning model assisted by Metacognitive Scaffolding on students' scientific literacy and numeracy skills through science learning in elementary schools. This learning model is expected to help students learn independently. Scientific literacy in this study includes identifying scientific facts and concepts and using scientific evidence as a basis for decision-making. In contrast, numerical literacy refers to basic mathematical skills, reading and analyzing quantitative data, and solving a problem based on the analysis process carried out.

\section{METHODS}

This study is quasi-experimental with a non-equivalent post-test-only control group design and a quantitative approach. This design is used because the population has been declared homogeneous and equal based on the analysis results in the preliminary study. The research design in more detail is presented in Table 1.

Table 1. Research Design

\begin{tabular}{ccc}
\hline Group & Treatment & Posttest \\
\hline Experiment & $\mathrm{X}$ & $\mathrm{O} 1$ \\
Control & - & $\mathrm{O} 2$ \\
\hline
\end{tabular}

Based on Table 1, the treatment for the experimental class is learning with the Murder learning model assisted by Metacognitive Scaffolding, while the control class learned with the model that the teacher usually use. The experimental and control classes were given a posttest after the treatment to determine the students' scientific literacy and numeracy skills. The population in this study was 173 elementary school students. This study used the random sampling technique because students were formed in study groups (study class). Through a lottery system twice, 60 students were chosen as samples (30 students as the experimental group, 30 as the control class).

In this study, the collected data were scores of scientific literacy and numeracy skills. Both data were obtained using scientific literacy and numeracy instruments. The instrument is in the form of 40 multiple choice test questions. The grid containing the dimensions of scientific literacy and numeracy assessment is presented in Table 2. The test assessment criteria are given a score of 1 if the answer is correct and 0 if the answer is incorrect. The instrument used went through several tests to ensure its validity and reliability. The validity of the instrument was tested using the Content Validity Index. The test results show that all instrument items are declared valid with a CVI value of 0.78 . Instrument reliability is calculated using the Kuder-Richardson formula (KR-20) and shows a coefficient of 0.889 with a very high-reliability category.

Table 2. Instrument Grid

\begin{tabular}{clc}
\hline \multicolumn{1}{c}{ Variable } & \multicolumn{1}{c}{ Dimension/Indicator } & Number of Items \\
\hline Scientific Literacy & Identifying scientific questions & 5 \\
& Explaining phenomena scientifically & 5 \\
& Using scientific evidence as a basis for decision making & 10 \\
Numeracy & Using a variety of numbers and symbols related to basic & 5 \\
& mathematics & \\
& $\begin{array}{l}\text { Analyzing the information displayed in the form of } \\
\text { graphs, tables, charts, and others }\end{array}$ & 7 \\
& Interpreting analysis data to predict and make decisions & 8 \\
\multicolumn{1}{c}{ Total } & 40 \\
\hline
\end{tabular}


The data analysis used is a descriptive statistical analysis technique by calculating the mean, median, mode, standard deviation, variance, maximum score, and minimum score. The technique used to analyze the data to test the research hypothesis is the MANOVA inferential analysis technique (Agung, 2014). Before testing the research hypothesis, the data distribution normality test, variance homogeneity test, multivariate homogeneity test, and multicollinearity test of the dependent variable were first carried out in the experimental and control groups (Agung, 2014). The IBM SPSS Statistics 21.0 program assisted the data analysis process.

\section{RESULTS AND DISCUSSION}

After treatment in the form of learning that applied the Murder learning model assisted by Metacognitive Scaffolding in the experimental group, data were collected in scientific literacy and numeracy data in the experimental and control groups. The data analysis was carried out descriptively and inferentially. Table 3 presents the descriptive analysis results of data in the experimental and control groups. Based on the results of the descriptive analysis, there is a reasonably high difference between the experimental and control groups.

Table 3. Descriptive Analysis Results of Data in Experimental and Control Groups

\begin{tabular}{lcccc}
\hline \multirow{2}{*}{ Descriptive Statistics } & \multicolumn{2}{c}{ Experimental Group } & \multicolumn{2}{c}{ Control Group } \\
\cline { 2 - 5 } & Science & Numeracy & Science & Numeracy \\
\hline $\mathrm{N}$ & 30 & 30 & 30 & 30 \\
Mean & 77.67 & 75.37 & 50.67 & 48.23 \\
Maximum Score & 94.00 & 94.00 & 67.00 & 64.00 \\
Minimum Score & 60.00 & 54.00 & 34.00 & 34.00 \\
Standard Deviation & 9.08 & 7.57 & 7.81 & 7.21 \\
\hline
\end{tabular}

The comparison of the average scores of rimental and control group is presented in Figure scientific literacy and numeracy skills in the expe- 1 .

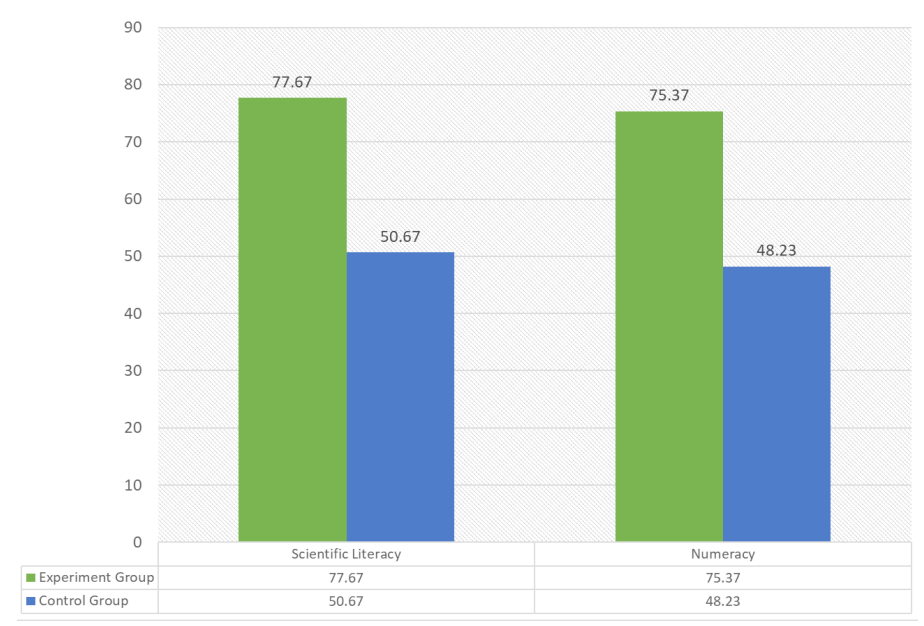

Figure 1. The Comparison of Scientific Literacy and Numeracy Skills in the Experimental and Control Groups

The results of the analysis prerequisite test show the following results. First, the normality test results for the data distribution indicate that the data on scientific literacy and numeracy skills come from groups of normally distributed data. It is obtained from the value of Sig. (0.200)>0.05. Second, the homogeneity of variance test with Levene's Test of Equality shows a significance value of 0.308 for data on scientific literacy skills and 0.925 for numeracy skills. The results of the multivariate normality test using the Box's Test of Equality of Covariance Matrices show an $F$ value of 0.594 with a significance value of 0.619 . Both of these results indicate that the research data is homogeneous. Third, the results of the multicollinearity test show a Tolerance value of 1,000 and a VIP of 1,000 . These results indicate no symptoms of multicollinearity between scientific literacy and numeracy data. 
The next step is to test the hypothesis using MANOVA. The results of the MANOVA test analysis show a significance value of 0.000 (Sig <0.05) for Pillai's Trace, Wilks' Lambda, Hotelling's Trace, Roy's Largest Root. This value indicates a simultaneous difference in scientific literacy and numeracy abilities between students who took lessons with the Murder learning model assisted by Metacognitive Scaffolding and students who took usual lessons. Furthermore, the partial effect on each dependent variable is presented in Table 4.

Tabel 4. Analysis Results of Tests of Between-Subjects Effects

\begin{tabular}{ccccccc}
\hline Source & $\begin{array}{c}\text { Dependent } \\
\text { Variable }\end{array}$ & $\begin{array}{c}\text { Type III Sum of } \\
\text { Squares }\end{array}$ & df & Mean Square & F & Sig. \\
\hline Corrected & $\mathrm{X} 1$ & 10935.000 & 1 & 10935.000 & 152.410 & 0.000 \\
Model & $\mathrm{X} 2$ & 11043.267 & 1 & 11043.267 & 201.651 & 0.000 \\
Intercept & $\mathrm{X} 1$ & 247041.667 & 1 & 247041.667 & 3443.227 & 0.000 \\
& $\mathrm{X} 2$ & 229154.400 & 1 & 229154.400 & 4184.370 & 0.000 \\
$\mathrm{~A}$ & $\mathrm{X} 1$ & 10935.000 & 1 & 10935.000 & 152.410 & 0.000 \\
& $\mathrm{X} 2$ & 11043.267 & 1 & 11043.267 & 201.651 & 0.000 \\
Error & $\mathrm{X} 1$ & 4161.333 & 58 & 71.747 & & \\
& $\mathrm{X} 2$ & 3176.333 & 58 & 54.764 & & \\
Total & $\mathrm{X} 1$ & 262138.000 & 60 & & & \\
& $\mathrm{X} 2$ & 243374.000 & 60 & & & \\
Corrected & $\mathrm{X} 1$ & 15096.333 & 59 & & & \\
Total & $\mathrm{X} 2$ & 14219.600 & 59 & & & \\
& & & & & & \\
\hline
\end{tabular}

Information:

$\mathrm{X} 1$ : Scientific Literacy

$\mathrm{X} 2$ : Numeracy

The tests of Between-Subjects Effects analysis revealed that the $\mathrm{X} 1$ variable (Science Literacy) has a significance value of $0.000(<0.05)$. The result indicates a significant effect of learning that applies the Murder learning model assisted by Metacognitive Scaffolding on elementary school students' scientific literacy skills. The tests also show that the X2 variable (Numeracy) also own a significance value of $0.000(<0.05)$, indicating a significant effect of learning that applies the Murder learning model assisted by Metacognitive Scaffolding on elementary school students' numeracy skills.

For several reasons, the Murder learning model assisted by Metacognitive Scaffolding is better than the conventional one. First, the Murder model assisted by Metacognitive Scaffolding emphasizes group responsibility. It causes each group to master, teach, and provide an understanding of the material that has been studied to other group friends. Students who have understood the material teach it to their friends. This process ma- kes students remember the material better (Gjems, 2013; Saguni, 2013; Rabgay, 2018). This learning activity makes each student have a responsibility so that each group understands the material as a whole, while in the conventional model, the responsibility given is to understand and complete a task individually. In addition, learning using the Murder model assisted by Metacognitive Scaffolding through these six stages given metacognitive scaffolding makes it easier for students to solve a problem in the learning process (Molenaar et al., 2010; Vrieling et al., 2012). The Murder model assisted by Metacognitive Scaffolding focuses on the assistance provided to students to solve problems and guides students in understanding, monitoring, evaluating, and providing reasons for problem-solving results (Kirana, 2013; Darmika et al., 2014). The results of this study are consistent with the results of previous studies. The suitability of the results of this study with previous studies is sufficient to strengthen the superiority of the Murder model assisted by Metacognitive 
Scaffolding compared to the conventional model in improving scientific literacy and numeracy skills.

Second, the Murder learning model assisted by Metacognitive Scaffolding makes it easier for students to understand the material to improve students' scientific literacy skills. Based on the comparison of the two learning models, the Murder model assisted by Metacognitive Scaffolding is better in providing opportunities for students to participate in learning to the fullest. The cooperative learning model makes it easier for students to understand the learning material (Qusyairi \& Sakila, 2018; Tan et al., 2021). From an empirical operational point of view in the presentation of learning, groups of students who learn to use the Murder model assisted by Metacognitive Scaffolding are facilitated with Murder-based teaching materials assisted by Metacognitive Scaffolding. In contrast, the conventional learning model group is facilitated by conventional worksheets. Interesting teaching materials will also affect students' enthusiasm and understanding in learning (Abd Majid et al., 2012; Lee \& Osman, 2012; Istuningsih et al., 2018). In the worksheets of murder assisted by Metacognitive Scaffolding, the presentation begins with exploring students' knowledge in opening learning. Students are encouraged to be able to answer the questions given. It also triggers the students' activeness in learning (Ruengtam, 2013; Dewi et al., 2017; Yanthi et al., 2017). Next, students are assigned into groups to discuss the worksheets, and each group consists of 4 people. The group learning is divided into two pairs (dyad 1, dyad 2) and assigns tasks to each pair (Purnamasari et al., 2016; Dewi et al., 2017). Unlike the case with conventional worksheets, these worksheets are packaged in the usual way as used by teachers in teaching in general. The presentation begins with the delivery of the basic theory, then continues with practice questions related to the material that has been taught. The presentation of learning with conventional worksheets does not give students the freedom to explore their prior knowledge so that students learn only based on teaching materials and clear instructions from the teacher.

The findings of previous research state that attractively packaged teaching materials would trigger student activity (Thuneberg et al., 2018; Cloonan et al., 2020). Other research also states that the Murder-type cooperative learning model can improve the learning atmosphere to be fun so that it affects students' learning outcomes (Ayunani, 2013; Darmika et al., 2014; Rahmadhani et al., 2019). This research finding implies that scien- ce learning can improve optimal literacy skills if it is based on the constructivism learning paradigm. The Murder model assisted by Metacognitive Scaffolding is one of the learning models based on learning theory or constructivism paradigms. In learning activities, the concepts studied are linked to students' real lives, thus providing considerable opportunities in a more meaningful science learning process. It builds students' knowledge through an active learning process based on the initial knowledge that they already have. In addition, the Murder model assisted by Metacognitive Scaffolding is concerned with individual student activities and contributions to group members to optimize cooperation between group members. It can train students to be more responsible for the tasks given in their groups. The Murder model assisted by Metacognitive Scaffolding can be favored to improve students' scientific literacy and numeracy skills.

\section{CONCLUSION}

There is a significant effect of the Murder learning model assisted by Metacognitive Scaffolding on students' scientific literacy and numeracy skills through science studies in elementary schools. The Murder model assisted by Metacognitive Scaffolding is one of the learning models based on learning theory or constructivism paradigms. In learning activities, the concepts studied are linked to the students' real lives, thus providing considerable opportunities in a more meaningful way science learning process. It builds students' knowledge through an active learning process based on the initial knowledge that they already have. In addition, the Murder model assisted by Metacognitive Scaffolding is concerned with individual student activities and contributions to group members to optimize cooperation between group members. It can train students to be more responsible for the tasks given in their groups. The Murder model assisted by Metacognitive Scaffolding can improve elementary school students' scientific literacy and numeracy skills.

\section{REFERENCES}

Abd Majid, M. S. Z. B., Ali, M. M. B. A., Rahim, A. A. B. A., \& Khamis, N. Y. B. (2012). The Development of Technical English Multimedia Interactive Module to Enhance Student Centered Learning (SCL). Procedia-Social and Behavioral Sciences, 67, 345-348.

Agung, A. A. G. (2014). Metodologi penelitian pendidikan. Malang: Aditya Media Publishing.

Andriyani, N. L., \& Suniasih, N. W. (2021). Development Of Learning Videos Based On Problem- 
Solving Characteristics Of Animals And Their Habitats Contain in Science Subjects On 6thGrade. Journal of Education Technology, 5(1).

Arisantiani, N. K., Putra, M., \& Ganing, N. N. (2017). Pengaruh Model Pembelajaran Childrens Learning in Science (CLIS) Berbantuan Media Lingkungan Terhadap Kompetensi Pengetahuan IPA. Journal of Education Technology, 1(2), 124-132.

Ayunani, M. (2012). Penerapan model pembelajaran kooperatif tipe murder (mood, understand, recall, degest, expand, review) untuk meningkatkan hasil belajar fisika siswa kelas VIII SMP negeri 16 palu. JPFT (Jurnal Pendidikan Fisika Tadulako Online), 1(1), 33-37.

Ayuni, I. A. S., Kusmariyatni, N., \& Japa, I. G. N. (2017). Pengaruh Model Pembelajaran Talking Stick Berbantuan Media Question Box Terhadap Hasil Belajar IPA Kelas V. Journal of Education Technology, 1(3), 183-190.

De Backer, L., Van Keer, H., \& Valcke, M. (2022). The functions of shared metacognitive regulation and their differential relation with collaborative learners' understanding of the learning content. Learning and Instruction, 77, 101527.

Bahari, N. K. I., Darsana, I. W., \& Putra, D. K. N. S. (2018). Pengaruh model discovery learning berbantuan media lingkungan alam sekitar terhadap hasil belajar IPA. Jurnal Ilmiah Sekolah Dasar, 2(2), 103-112.

Binali, T., Tsai, C. C., \& Chang, H. Y. (2021). University students' profiles of online learning and their relation to online metacognitive regulation and internet-specific epistemic justification. Computers \& Education, 175, 104315.

Chuprina, S., Postanogov, I., \& Nasraoui, O. (2016). Ontology based data access methods to teach students to transform traditional information systems and simplify decision making process. Procedia Computer Science, 80, 1801-1811.

Cloonan, M. R., Cloonan, D. J., Schlitzkus, L. L., \& Fingeret, A. L. (2020). Learners with Experience in Surgical Scrub Benefit from Additional Education with an Interactive E-Learning Module. Journal of the American College of Surgeons, 231(4), e196.

Darmika, N. K., Suma, K., \& Suastra, I. W. (2014). Pengaruh model pembelajaran kooperatif murder terhadap motivasi belajar dan prestasi belajar IPA siswa SMP. Jurnal Pendidikan dan Pembelajaran IPA Indonesia, 4(1).

Demitra, \& Sarjoko. (2018). Effects of Handep Cooperative Learning Based on Indigenous Knowledge on Mathematical Problem Solving Skill. International Journal Of Instruction, 11(2), 103-114.

Dewi, N. P. R. S., Ganing, N. N., \& Suadnyana, I. N. (2017). Pengaruh Model Pembelajaran Kooperatif Tipe Think Pair Share Berbantuan Mind Mapping Terhadap Kompetensi Pengetahuan IPA Siswa Kelas V SD Gugus Kompyang Su- jana Denpasar Utara. MIMBAR PGSD Undiksha, 5(2).

Duane, B. T., \& Satre, M. E. (2014). Utilizing constructivism learning theory in collaborative testing as a creative strategy to promote essential nursing skills. Nurse Education Today, 34(1), 31-34.

Elisabet, E., Relmasira, S. C., \& Hardini, A. T. A. (2019). Meningkatkan Motivasi dan Hasil Belajar IPA dengan Menggunakan Model Pembelajaran Project Based Learning (PjBL). Journal of Education Action Research, 3(3), 285-291.

Gjems, L. (2013). Teaching in ECE: Promoting children's language learning and cooperation on knowledge construction in everyday conversations in kindergarten. Teaching and teacher education, 29, 39-45.

Haryono, H. E. (2020). The Influence of Cooperative Learning Model Type Group Investigation Toward Results of Learning Science Materials of Students. Jurnal Ilmiah Pendidikan Fisika, 4(1), 1.

Istuningsih, W., Baedhowi, B., \& Sangka, K. B. (2018). The effectiveness of scientific approach using e-module based on learning cycle 7e to improve students' learning outcome. International Journal of Educational Research Review, 3(3), 75-85.

Kirana, K. (2013). Penerapan Model Pembelajaran Kooperatif Tipe Murder Pada Materi Persamaan Garis Lurus. MATHEdunesa, 2(1).

Koopman, M., Den Brok, P., Beijaard, D., \& Teune, P. (2011). Learning processes of students in pre-vocational secondary education: Relations between goal orientations, information processing strategies and development of conceptual knowledge. Learning and Individual Differences, 21(4), 426-431.

Kurniawati, M. W., Anitah, S., \& Suharno, S. (2017). Developing learning Science teaching materials based on scientific to improve students learning outcomes in Elementary School. European Journal of Education Studies.

Lee, T. T., \& Osman, K. (2012). Interactive multimedia module in the learning of electrochemistry: effects on students' understanding and motivation. Procedia-Social and Behavioral Sciences, 46, 1323-1327.

Liebech-Lien, B. (2021). Teacher teams-A support or a barrier to practising cooperative learning?. Teaching and Teacher Education, 106, 103453.

Lo, J. H., Lai, Y. F., \& Hsu, T. L. (2021). The Study of AR-Based Learning for Natural Science Inquiry Activities in Taiwan's Elementary School from the Perspective of Sustainable Development. Sustainability, 13(11), 6283.

Maison, M., Haryanto, H., Ernawati, M. D. W., Ningsih, Y., Jannah, N., Puspitasari, T. O., \& Putra, D. S. (2020). Comparison of Student Attitudes towards Natural Sciences. International Journal of Evaluation and Research in Education, 9(1), 5461. 
Molenaar, I., Van Boxtel, C. A., \& Sleegers, P. J. (2010). The effects of scaffolding metacognitive activities in small groups. Computers in Human Behavior, 26(6), 1727-1738.

Novianti, D. (2017). Penerapan Model Kooperatif Teknik Paired Story telling untuk Meningkatkan Kemampuan Bercerita Siswa Kelas V pada Pembelajaran Bahasa Indonesia MIN Mesjid Raya Banda Aceh (Doctoral dissertation, UIN Ar-Raniry Banda Aceh).

Purnamasari, I., \& Tanuatmodjo, H. (2016). Interaction Between the Type of School and Learning Outcomes in Student's Soft Skills Enhancement through Cooperative Learning Model (Quasi Experiment on Vocational Students in Bandung). Procedia-Social and Behavioral Sciences, 219, 838-845.

Nurhusain, M. (2017). Impact analysis of cooperative learning model application type two stay two stray (tsts) toward learning outcomes of mathematics. Journal STKIP YPUP.

Pande, M., \& Bharathi, S. V. (2020). Theoretical foundations of design thinking-A constructivism learning approach to design thinking. Thinking Skills and Creativity, 36, 100637.

Paramitha, I. D. A. A., Made Sulastri, M. P., \& Margunayasa, I. G. (2016). Pengaruh model inkuiri terbimbing, gaya kognitif, dan motivasi berprestasi terhadap pemahaman konsep IPA siswa kelas V SD. MIMBAR PGSD Undiksha, 4(1).

Parmin, P., Sajidan, S., Ashadi, A., \& Sutikno, S. (2015). Skill of teacher candidates in integrating the concept of science with local wisdom. Jurnal Pendidikan IPA Indonesia, 4(2).

Purnami, W., Sarwanto, S., Suranto, S., Suyanti, R., \& Mocerino, M. (2021). Investigation of Science Technology Ecocultural Society (STEcS) Model to Enhance Eco Critical Thinking Skills. Journal of Innovation in Educational and Cultural Research, 2(2), 77-85.

Qusyairi, L. A. H., \& Sakila, J. (2018). Pengaruh Model Cooperative Learning Tipe Inside-Outside Circle (IOC) terhadap Prestasi Belajar dengan Memperhatikan Minat Belajar Matematika. PALAPA, 6(1), 34-49.

Rabgay, T. (2018). The Effect of Using Cooperative Learning Method on Tenth Grade Students' Learning Achievement and Attitude towards Biology. International Journal of Instruction, 11(2), 265-280.

Rahmadhani, E., Gradini, E., \& Firmansyah. (2019). Literasi Matematika Siswa Melalui Metode Murder (Mood, Understand, Recall, Digest, Expand, Review). Al Khawarizmi: Jurnal Pendidikan dan Pembelajaran Matematika, 3(2), 26-40.

Ratih, N. K. (2017). Pengaruh Model Pembelajaran Numbered Head Together Berbantuan Multimedia Interaktif Terhadap Hasil Belajar IPA. MIMBAR PGSD Undiksha, 5(2), 1-9.
Redhana, I. W. (2013). Model Pembelajaran Berbasis Masalah Dan Pertanyaan Socratik Untuk Meningkatkan Keterampilan Berpikir Kritis Siswa. Jurnal Cakrawala Pendidikan, 3, 351-365.

Royanto, L. R. (2012). The Effect of An Intervention Program based on Scaffolding to Improve Metacognitive Strategies in Reading: A Study of Year 3 Elementary School Students in Jakarta. Procedia - Social and Behavioral Sciences, 69(Iceepsy), 1601-1609.

Ruengtam, P. (2013). Modeling of Cooperative/Collaborative Learning Technique: A Case Study of Interior Architectural Program. Procedia - Social and Behavioral Sciences, 105.

Saguni, F. (2013). Efektivitas Metode Problem Based Learning, Cooperative Learning Tipe Jigsaw, Dan Ceramah Sebagai Problem Solving Dalam Matakuliah Perencanaan Pembelajaran. Cakrawala Pendidikan, 1(2).

Serli, Murdiana, I. N., \& Karniman, T. S. (2020). Penerapan Model Pembelajaran Kooperatif Tipe Murder Untuk Meningkatkan Hasil Belajar Siswa Pada Materi Luas Permukaan Dan Volume Limas Di Kelas Viii H Smp Negeri 15 Palu. Jurnal Elektronik Pendidikan Matematika Tadulako, 8(1).

Suantara, I. K. T., Ganing, N. N., Agung, I. G., \& Wulandari, A. (2019). Pengaruh Model Pembelajaran Think Pair Share Berbantuan Media TTS terhadap Kompetensi Pengetahuan IPA. Jurnal Ilmiah Sekolah Dasar, 3(4), 473-480.

Suari, Ni, P. (2018). Penerapan Model Pembelajaran Problem Based Learning Untuk Meningkatkan Motivasi Belajar IPA. Jurnal Ilmiah Sekolah Dasar, 2(3), 241-247.

Subali, B., Kumaidi, Aminah, N. S., \& Sumintono, B. (2019). Student achievement based on the use of scientific method in the natural science subject in elementary school. Jurnal Pendidikan IPA Indonesia, 8(1), 39-51.

Suwannaphisit, S., Anusitviwat, C., Hongnaparak, T., \& Bvonpanttarananon, J. (2021). Expectations on online orthopedic course using constructivism theory: A cross-sectional study among medical students. Annals of Medicine and Surgery, 67.

Tan, J., Yang, Z., Cheng, Y., Ye, J., Wang, B., \& Dai, Q. (2021). SRAGL-AWCL: A two-step multiview clustering via sparse representation and adaptive weighted cooperative learning. Pattern Recognition, 117.

Thuneberg, H. M., Salmi, H. S., \& Bogner, F. X. (2018). How creativity, autonomy and visual reasoning contribute to cognitive learning in a STEAM hands-on inquiry-based math module. Thinking Skills and Creativity, 29.

Vrieling, E. M., Bastiaens, T. J., \& Stijnen, S. (2012). Effects of increased self-regulated learning opportunities on student teachers' metacognitive and motivational development. International 
Journal of Educational Research, 53.

Wardani, R. K., \& Syofyan, H. (2018). Pengembangan Video Interaktif pada Pembelajaran IPA Tematik Integratif Materi Peredaran Darah Manusia. Jurnal Ilmiah Sekolah Dasar, 2(4), 371.

Wesiak, G., Steiner, C. M., Moore, A., Dagger, D., Power, G., \& Berthold, M. (2014). Iterative augmentation of a medical training simulator: Effects of affective metacognitive scaffolding. Computers \& Education, 76, 13-29.

Widani, N. K. T., Sudana, D. N., \& Agustiana, I. G. A. T. (2019). Pengaruh Model Pembelajaran Inkuiri Terbimbing Terhadap Hasil Belajar IPA Dan Sikap Ilmiah Pada Siswa Kelas V SD Gugus I Kecamatan Nusa Penida. Journal of Edu- cation Technology, 3(1), 15-21.

Wijanarko, Y. (2017). Model Pembelajaran Make a Match Untuk Pembelajaran IPA Yang Menyenangkan. Taman Cendekia: Jurnal Pendidikan $K e-S D-A n, 1(1), 52$.

Yanthi, N. M. D. W., Japa, \& Tegeh. (2017). Pengaruh Model Pembelajaran Kooperatif Tipe NHT dan Motivasi Belajar Terhadap Hasil Belajar IPA. MIMBAR PGSD Undiksha, 5(2), 1-10.

Zheng, L., Li, X., Zhang, X., \& Sun, W. (2019). The effects of group metacognitive scaffolding on group metacognitive behaviors, group performance, and cognitive load in computer-supported collaborative learning. The Internet and Higher Education, 42. 